\title{
Mothers' Economic Well-Being in Sole and Joint Physical Custody Families
}

\author{
Lara Augustijn $^{1} \mathbb{D}$
}

Accepted: 29 December 2021 / Published online: 17 January 2022

(c) The Author(s) 2022

\begin{abstract}
Previous research has repeatedly shown that separation or divorce can lead to a substantial decline in economic resources, and that it is mostly mothers who suffer from the severe economic consequences. Because it has also been established that the post-separation care arrangement that a family practices is a central factor in explaining mothers' poor economic situations after family dissolution, this study investigated the association between physical custody arrangements (sole physical custody, asymmetric joint physical custody, and symmetric joint physical custody) and the economic well-being of 1018 residential mothers from the Family Models in Germany study. The results of the ordered logistic regression models showed that mothers in asymmetric and symmetric joint physical custody families reported higher levels of economic well-being than mothers with sole physical custody. When controlling for a set of confounders, the differences between mothers with sole physical custody and symmetric joint physical custody disappeared, which suggests that the economic advantages of mothers with symmetric joint physical custody can be fully explained by factors like the mothers' working hours, their personal net income, their partnership status, and the fairness of their financial arrangement with their former partner. In contrast, the relationship between asymmetric joint physical custody and mothers' economic situations remained significant even after control variables were included in the regression models. However, the question of what role selection processes among parents play in explaining the observed differences in post-separation economic well-being between mothers in sole and joint physical custody families remains open.
\end{abstract}

Keywords Asymmetric joint physical custody $\cdot$ Economic well-being $\cdot$ Family Models in Germany $\cdot$ Mothers $\cdot$ Sole physical custody $\cdot$ Symmetric joint physical custody

It is well-established knowledge that separation or divorce can have detrimental consequences for the partners' economic situations, as it can lead to a substantial decline in their economic resources (Mortelmans, 2020; Osborne et al., 2012; Raley \& Sweeney, 2020). However, previous empirical studies have also shown that there are significant gender differences in post-separation economic well-being. Although the differences between men's and women's experiences following divorce have decreased due to factors like women's increasing labor market participation and the expansion of public childcare, women are still more likely than men to suffer economically after union dissolution (Andreß et al., 2006; Assave et al., 2007; Köppen et al.,

Lara Augustijn

lara.augustijn@uni-due.de

1 Department of Sociology, University of Duisburg-Essen, Lotharstrasse 65, 47057 Duisburg, Germany
2020; Leopold, 2018; Poortman, 2000). One central cause of women's greater vulnerability following separation is that in European countries, women are usually awarded sole physical custody of their children after family dissolution (Assave et al., 2007). This means that most children whose parents have separated live either mainly or exclusively with their mother, and have no or only limited contact with their nonresidential father (Cancian et al., 2014). As a result, single mothers tend to shoulder most, if not all, of the childrearing responsibilities in post-separation families, which can make it difficult for them to participate in the labor market (Bakker \& Karsten, 2013).

However, in recent decades, there has been a noticeable trend toward fathers being increasingly involved in their children's lives after separation (see, for example, Amato et al., 2009), and this trend has been accompanied by the growing prevalence of joint physical custody in many European countries (Spruijt \& Duindam, 2009). Joint physical custody is an 
arrangement in which children whose parents have separated or divorced spend considerable amounts of time with both their mother and their father (usually not less than $30 \%$ of the time with each parent). Thus, this arrangement differs from the more traditional post-separation care arrangement of sole physical custody in which children spend less than $30 \%$ of the time with their non-residential parent (Steinbach, 2019). Due to the increasing prevalence of joint physical custody and its potential implications for daily life in post-separation families, this care arrangement has, in recent years, received more attention from the public and from researchers. While the overwhelming majority of the existing studies on this topic have focused on the effects that practicing joint physical custody may have on children's adjustment to parental separation, scholars have largely neglected the well-being of the parents involved in such arrangements (Sodermans et al., 2015). Nevertheless, previous research was able to identify some pathways through which practicing joint physical custody may enhance parents' well-being (Bauserman, 2012; Steinbach, 2019), and there are also reasons to assume that practicing joint physical custody may affect parents' economic well-being.

Therefore, this study explores the relationship between physical custody arrangements and the economic wellbeing of 1018 residential mothers in post-separation families. Based on data from the Family Models in Germany (FAMOD) study that was conducted in 2019 , ordered logistic regression models were estimated. A special feature of this study is that it is able to differentiate not only between sole and joint physical custody arrangements, but also between the effects that asymmetric joint physical custody (in which children live between 30 and $49 \%$ of the time with their non-residential parent) and symmetric joint physical custody (a 50:50 arrangement in which children divide their time equally between their parents) may have on the economic well-being of mothers. Thus, this study fills a significant gap in the literature on joint physical custody and parental well-being.

\section{Background}

Leopold (2018) has argued that four factors need to be considered when seeking to explain why the economic consequences of separation tend to be more severe for women than for men: (1) the gender-specific division of labor prior to separation and women's lower human capital; (2) a significant loss of income for women that is often not compensated for by alimony payments; (3) insufficient child support; and (4) women's restricted earning opportunities. While in a relationship, the man tends to be the family's primary breadwinner (Raley \& Sweeney, 2020), whereas the woman is more likely to take on domestic work and childcare responsibilities
(Poortman, 2000; Radenacker, 2020). Due to this traditional division of labor and the tendency of women to temporarily or permanently drop out of the labor force, women are often financially dependent on their partner (Jansen et al., 2009). Moreover, women's tendency to have a loose attachment to the labor market and a fragmented work career is associated with lower average wages (Assave et al., 2007), shorter working hours (Poortman, 2000), and lower human capital (Leopold, 2018). Because the "economically weaker party loses access to the pooled household income" (Radenacker, 2020, p. 68) when the relationship ends, women often experience a significant loss of economic resources in the wake of a separation. In addition, factors like having a fragmented work career and lower human capital often make it more difficult for women to re-enter the labor market and to increase their earnings after a separation (Kessler, 2018; Poortman, 2000; Struffolino \& Mortelmans, 2018). Another key factor that contributes to women's greater economic challenges is that the traditional division of labor continues after family dissolution, as the majority of women continue to be their children's main caregiver (Poortman, 2000). This arrangement can have further negative implications for a woman's labor market position and her associated economic situation, as it drastically limits the time the woman can spend on paid employment. Moreover, when a divorced woman leads a household in which children are present, the household's economic needs may be difficult to meet with the mother's restricted earning opportunities and child support payments alone (Bröckel \& Andreß, 2015; Poortman, 2000).

\section{Theoretical Considerations on the Relationship Between Joint Physical Custody and Mothers' Economic Well-Being}

The effects of joint physical custody on the economic situations of residential mothers are not easy to determine, because in addition to the possibility that there is a causal relationship between them, the issue of selection processes needs to be addressed. Parents who choose joint physical custody presumably have a range of positive characteristics that distinguish them from parents who select traditional care arrangements, particularly when the prevalence of joint physical custody is still comparatively low in a given country and when joint physical custody is not imposed upon parents by law (Emery et al., 2005; Poortman \& van Gaalen, 2017). In line with this assumption, previous research has shown that mothers in joint physical custody families tend to have higher educational levels than mothers with sole physical custody (Juby et al., 2005). In addition, parents who opt for joint physical custody are known to have more egalitarian gender role attitudes than parents who practice sole physical custody (Kitterød \& Lyngstad, 2012; Poortman $\&$ van Gaalen, 2017). Parents who have egalitarian gender 
role attitudes are, in turn, more likely to have an egalitarian division of labor. Thus, in these families, the mother is more likely to have been active in the labor market prior to the separation (Juby et al., 2005). Furthermore, the parents' income seems to be an important predictor of their choice of post-separation care arrangements, with parents who have an above-average income being more likely to practice joint physical custody (Bakker \& Mulder, 2013; Cancian et al., 2014; Cashmore et al., 2010; Meyer et al., 2017). Scholars have attributed this relationship to the additional costs that are associated with practicing joint physical custody (Cancian et al., 2014; Poortman \& van Gaalen, 2017), including the costs of maintaining two suitable homes and having two sets of furniture, clothes, and toys for the children (Bakker \& Mulder, 2013). Moreover, because there is some evidence that joint physical custody is associated with frequent transitions between the parents' households (Steinbach \& Augustijn, 2021), this care arrangement may also involve higher travel costs (Vanassche et al., 2017), especially when the parents live far away from each other.

Taken together, these findings indicate that mothers in joint physical custody families differ significantly from their counterparts in sole physical custody families in terms of their pre-separation division of labor and their level of attachment to the labor market. Therefore, mothers with joint physical custody should be in a more advantageous position after separation, mainly because they are more likely to have a high educational level, a continuous work career, and a high level of human capital. Accordingly, a positive association between joint physical custody and mothers' economic well-being after family dissolution may be either fully or at least partially explained by these mothers having more advantaged starting conditions after separation.

One central argument for the existence of a causal relationship between joint physical custody and mothers' economic well-being is that mothers with sole physical custody typically bear the primary financial responsibility for their children, which puts them in a disadvantaged economic position (Kessler, 2018). Mothers with sole custody often face pressure to spend substantial amounts of money on their children's clothes, food, toys, and other expenses that may not be fully covered by the mothers' income, child support payments, or welfare support (Assave et al., 2007; Bröckel \& Andreß, 2015). In comparison to their counterparts in sole physical custody families, children living in joint physical custody families spend more time with their father, particularly when the family practices symmetric joint physical custody. As research has suggested that father-child contact and child support are closely related (Cheadle et al., 2010; Hofferth et al., 2010), it is plausible to assume that practicing joint physical custody may give the father more incentives to provide his children with financial resources after family dissolution (Turunen, 2017), and thus reduces the residential mother's economic strains.

However, in this context the country's legal system, and particularly its regulations concerning child support, has to be considered. In Germany, for instance, the non-residential parent in an asymmetric joint physical custody arrangement (i.e., the parent with whom the child spends the smaller proportion of time) may have to pay the full amount of child support, even if the family has, for example, a 40:60 arrangement. In contrast, courts are more likely to make adjustments to child support settlements in a symmetric joint physical custody arrangement, although child support payments may not be completely eliminated. This is because the German legal system assumes that sole physical custody is the norm, and thus has a narrow definition of joint physical custody as being a 50:50 arrangement (Schneider, 2021). As a result of these regulations, mothers in asymmetric joint physical custody families may have higher levels of economic wellbeing than mothers with symmetric joint physical custody, as they can benefit from sharing the physical custody of their children with the father while receiving higher child support payments.

Another reason why mothers in post-separation families may tend to benefit economically from practicing joint physical custody is that they spend less time on childrearing than single mothers with sole physical custody. The more time mothers invest in childcare tasks, the less time they can spend on other activities, including paid employment (Bakker \& Karsten, 2013). As children live for substantial amounts of time with both parents in a joint physical custody arrangement, mothers with joint physical custody have more time to invest in the labor market, and should, therefore, have a significant economic advantage over mothers with sole physical custody, particularly in countries where mothers' labor market participation depends on the availability and affordability of public childcare (Hancioglu \& Hartmann, 2014; Kessler, 2018). In addition, practicing joint physical custody should make it easier for mothers not only to engage in paid employment, but also to work in more demanding jobs; for example, in jobs that require them to commute or work longer hours (Bakker \& Karsten, 2013; Bonnet et al., 2018).

Furthermore, research has shown that repartnering can be a pathway to economic recovery for women after family dissolution (Jansen et al., 2009; Raley \& Sweeney, 2020). Separated mothers' chances of finding a new partner generally depend on three factors: needs, opportunities, and attractiveness (Becker, 1981; de Graaf \& Kalmijn, 2003; Ivanova et al., 2013). Although practicing joint physical custody may reduce a mother's financial need to have a new relationship, it can improve her chances of repartnering by increasing her opportunities to meet potential partners by providing her with more leisure time (Sodermans et al., 2015). Moreover, 
practicing joint physical custody may boost a mother's attractiveness for potential partners, as having residential children from a previous relationship significantly reduces a mother's attractiveness (de Graaf \& Kalmijn, 2003), whereas being "childless" (Sodermans et al., 2015, p. 260) for considerable periods of time should increase a mother's attractiveness. Based on these theoretical considerations, one would expect to find that mothers with symmetric joint physical custody who are "childless" half of the time benefit economically from having more time to invest in the labor market and in social activities, whereas mothers with asymmetric joint physical custody benefit less economically because they spend more time with their children.

\section{Empirical Evidence of the Relationship Between Joint Physical Custody and Mothers' Economic Well-Being}

Empirical evidence on the association between joint physical custody and parents' economic well-being is still extremely rare. The only existing study that has examined the direct relationship between physical custody arrangements and parents' economic well-being with data from Germany found only a weak correlation between practicing joint physical custody and the parents' satisfaction with their economic situations that disappeared after controlling for socio-economic variables like the parents' educational levels and employment status (Köppen et al., 2020). However, the findings of this study need to be interpreted with caution, as the survey that the statistical analysis was based on (Panel Analysis of Intimate Relationships and Family Dynamics, pairfam) did not allow for a clear distinction to be made between sole and joint physical custody arrangements. Nevertheless, there are other studies that provide indirect evidence that joint physical custody has a positive effect on mothers' economic well-being. For instance, a qualitative study from the Netherlands suggested that mothers with sole physical custody had greater difficulties in combining paid employment, childcare, and leisure activities than mothers in joint physical custody families. The authors ascribed the observed difficulties to different levels of commitment in the work and care domains among mothers in post-separation families, and particularly to single mothers having higher levels of commitment to their role as their children's main caregiver (Bakker \& Karsten, 2013). Corroborating these findings, a French study that explored divorced women's participation in the labor market found that mothers in joint physical custody families were more likely to be in paid employment than mothers in sole physical custody families, with the differences between the two groups amounting to 16 percentage points. In addition, the results of the analysis indicated that practicing joint physical custody was particularly beneficial to mothers who were far removed from the labor market
(Bonnet et al., 2018). Moreover, research has shown that mothers' chances of repartnering were higher when they practiced joint physical custody rather than sole physical custody. Indeed, the authors of this study found a causal link between physical custody arrangements and mothers' likelihood of finding a new partner (Schnor et al., 2017).

\section{Method}

\section{Data and Analytical Sample}

The data for the statistical analysis come from the Family Models in Germany (FAMOD) study (Steinbach et al., 2020). This survey is a convenience sample that was funded by the German Research Foundation and conducted in 2019. The primary objective of the FAMOD study was to investigate the well-being of post-separation families in Germany, although a special focus was on joint physical custody families. The FAMOD study includes detailed information about the family life of 1554 nuclear, sole physical custody, and joint physical custody families with at least one child under the age of 15 . The sample was stratified by (a) family model (nuclear, sole physical custody, and joint physical custody families) and (b) age of a selected target child (0-6 years and 7-14 years). Another prerequisite for a post-separation family to be included in the survey was that the target child had to have contact with both of his or her biological parents. The FAMOD survey employed a multi-actor design, and thus provides researchers with information from four groups of respondents, including the residential parent of a selected target child (anchor respondent) (Kantar Public, 2020; Steinbach et al., 2020). For the present study, information provided by these respondents was used.

Because the prevalence of joint physical custody families is still comparatively low in Germany, and because it is not possible to identify these families with official statistics, joint physical custody families had to be oversampled in the FAMOD study to achieve sufficient case numbers. Thus, the respondents were recruited by professional interviewers from Kantar Public, who identified families with different physical custody arrangements, and used snowball procedures to find rare subgroups. Although the sampling procedure used in the FAMOD study was not random, Steinbach et al. (2020) showed that the anchor respondents in the FAMOD study were quite similar to the respondents in other surveys with samples that are representative of the German population of parents in terms of several of their socio-demographic characteristics.

The FAMOD study surveyed a total of 1554 families. In a first step, all nuclear families $(n=321)$ and all male anchor respondents $(n=154)$ were excluded from the sample, as this analysis focuses on the economic well-being of 
mothers after family dissolution. In addition, some respondents had to be deleted from the sample because the physical custody arrangement that these families practiced could not be determined $(n=46)$. Next, all father sole physical custody families (i.e., arrangements in which the children spent more than $70 \%$ of the time with the father) and all asymmetric joint physical custody families in which the mother was not the target child's residential parent (i.e., arrangements in which children spent between 30 and $49 \%$ of the time with the mother) were dropped for the sake of comparability, as these cases were too small in number to allow for comparisons $(n=3)$. Finally, all cases with missing values on the dependent variable were excluded from the analysis $(n=12)$, which resulted in an analytical sample that consisted of 1018 residential mothers in post-separation families given that all missing values on the covariates were imputed by means of multiple imputation. Of the mothers in the analytical sample, $63.0 \%$ practiced sole physical custody $(n=641), 21.6 \%$ practiced asymmetric joint physical custody $(n=220)$, and $15.4 \%$ practiced symmetric joint physical custody $(n=157)$.

\section{Measures}

\section{Dependent Variable}

The residential mother's economic well-being was determined by the question: "How is the financial situation in your household?" The response categories to this question ranged from very bad (0) to very good (5). Because the distribution of respondents was skewed, with almost twothirds of respondents assessing their financial situation as either good or very good, the variable was recoded, dividing the sample into three groups: very bad to partly bad ( 0 , consisting of respondents with either a very bad, a bad, or a partly bad financial situation), good (1), and very good (2). To test whether the proportional odds assumption was violated, a likelihood ratio test $\left(\chi^{2}=13.60 ; p>\chi^{2}=0.1375\right)$ and a Brant test $\left(\chi^{2}=15.56 ; p>\chi^{2}=0.077\right)$ were carried out. The results of both tests confirmed that the proportional odds assumption was met, and that it was, therefore, legitimate to estimate ordered logistic regression models. Instead of using a more objective indicator of mothers' post-separation economic well-being (e.g., their income), this study focuses on mothers' subjective assessment of their economic situation as the dependent variable. This approach was chosen because early research has pointed out that "objective measures [of well-being] fail to take into account quality components and mental processes that are important to individual perceptions" (Needles Fletcher \& Lorenz, 1985, p. 333), and thus stressed the importance of subjective measurements of economic well-being.

\section{Independent Variable}

The independent variable is the physical custody arrangement of the anchor respondents' target child. Information on physical custody arrangements was gathered through the use of a residential calendar (see also Sodermans et al., 2014). With this calendar, respondents could give detailed information about the days and nights of a typical month on which the target child was living with either the mother or the father. If a child was living less than $30 \%$ of his or her time with the father, the family was identified as practicing sole physical custody (0). Correspondingly, a family in which the target child was living between 30 and $49 \%$ of his or her time with the father was identified as practicing asymmetric joint physical custody (1), whereas a family in which the child was spending $50 \%$ of his or her time with each parent was identified as practicing symmetric joint physical custody (2).

\section{Covariates}

Based on the year of data collection and the year in which the respondents were born, the mother's age, which ranged from 20 to 58 years, could be calculated. The mother's educational level was determined based on information about the respondents' highest school-leaving certificate. Accordingly, the sample was split into three groups: low educational level ( 0 , no school-leaving certificate or the lowest formal qualification of Germany's tripartite secondary school system), medium educational level (1, intermediary secondary qualification), and high educational level (2, at minimum, a certificate fulfilling entrance requirements to study at a university of applied sciences). To assess the mother's weekly working hours, the following question was used: "What are, on average, your real weekly working hours, including overtime? For this calculation, please take into account all of your jobs." Based on the respondents' answers, the analytical sample was divided into four groups: $0 h(0), 1-19 h$ (1), 20-36 h (2), and more than $36 h$ (3). To measure the mother's personal monthly net income, the following question was used: "Combining all income types: What was your earned income last month? We are interested in your net income; that is, the amount that remains after deduction of taxes and contributions to retirement, unemployment, and health insurance. Please include regular payments such as unemployment benefit, pension, housing allowances, child support, student loans/allowances (BAföG), alimony, etc." Based on their answers to this question, the respondents could be divided into four groups: less than 1500 euros (0), 1500 euros to less than 2000 euros (1), 2000 euros to less than 3000 euros (2), and 3000 euros or more (3). The mother's number of children was determined using the question: "How many children do you have?" This question referred not only to biological children, but also to adopted 
children or stepchildren if they were living in the respondent's household or had ever lived there: one child (0), two children (1), and more than two children (2). The age of the mother's youngest child ranged between zero and 14 years. Furthermore, the mother's partnership status was controlled for by differentiating between two groups of respondents: no partner (0) and partner (1). The time since the separation from the child's father was assessed by subtracting the year in which the relationship between the former partners ended from the year of data collection, with the time ranging between zero and 15 years. Finally, the fairness of the financial arrangement between the parents concerning the target child was measured using the question: "When you think about [target child]: In your opinion, how fair is the financial arrangement with the biological father? Think about all the expenses and earnings that have to do with [target child]." The response categories for this question were: "The other biological parent takes way more than his fair share"; "The other biological parent takes a bit more than his fair share"; "The other biological parent takes approximately his fair share"; "The other biological parent takes a bit less than his fair share"; and "The other biological parent takes much less than his fair share." For the statistical analysis, two groups of respondents were identified. Families in which the father took either less or more than his fair share were considered to have an unfair financial arrangement (0), whereas families in which the father took his fair share were considered to have a fair financial arrangement (1). The descriptive statistics for all variables are displayed in Table 1.

\section{Results}

To investigate the association between physical custody arrangements (sole physical custody, asymmetric joint physical custody, and symmetric joint physical custody) and residential mothers' economic well-being, ordered logistic regression models were estimated (see Table 2). Because only the target child's physical custody arrangement was considered in the analysis, the possibility cannot be ruled out that the mother's economic well-being was influenced by other physical custody arrangements that she practiced if she had other children living in different types of post-separation care arrangements. Thus, to strengthen the conclusions drawn from this study, robustness checks were carried out for a subsample of mothers who practiced only one type of physical custody arrangement $(n=997)$. The results demonstrated that only $2.1 \%$ of all mothers in the analytical sample actually practiced more than one physical custody arrangement $(n=21)$. Unsurprisingly, the relationship between the physical custody arrangements and the respondents' economic well-being did not differ between the subsample and the full sample (results are not shown here, but are available on request).

Table 2 summarizes the results of the ordered logistic regression models for the full sample of residential mothers. The bivariate results in Model 1 show a statistically significant relationship between the physical custody arrangements and mothers' post-separation economic well-being, with mothers who practiced either asymmetric joint physical custody $(O R 2.20, p<0.001)$ or symmetric joint physical custody (OR 1.87, $p<0.001$ ) having higher odds of reporting higher levels of economic well-being than mothers with sole physical custody of their children. However, after including in Model 2 the mother's socio-demographic characteristics, the time since her separation from her former partner, and her perception of the fairness of her financial arrangement, the initially observed differences between mothers in sole physical custody and symmetric joint physical custody families disappeared. By contrast, mothers with asymmetric joint physical custody still had higher odds of having higher levels of economic well-being than mothers with sole physical custody, even when all covariates were held constant (OR 1.78, $p<0.001$ ).

The findings for the covariates in Model 2 suggest that there was a significant relationship between mothers' weekly working hours and their economic well-being. Compared to mothers who were working more than $36 \mathrm{~h}$ per week, mothers who were working either $0 \mathrm{~h}(O R 0.21, p<0.001)$ or between 20 and $36 \mathrm{~h}$ per week $(O R 0.54, p<0.001)$ reported lower levels of economic well-being. However, a rather surprising finding was that mothers who worked between one and $19 \mathrm{~h}$ did not differ from mothers who worked more than $36 \mathrm{~h}$ per week in their assessments of their economic situations. Unsurprisingly, there was a positive association between the mothers' monthly personal net income and their economic well-being, as mothers with an income between 2000 euros and less than 3000 euros $(O R 1.98, p<0.01)$ or with an income of 3000 euros or more $(O R 2.92, p<0.01)$ had higher odds of reporting higher levels of economic well-being than mothers with an income of less than 1500 euros per month. While there were no significant differences between mothers with one child and those with two children, having more than two children significantly lowered the mothers' odds of reporting high levels of economic wellbeing $(O R 0.52, p<0.05)$. Moreover, mothers with a partner had higher odds of reporting higher levels of economic wellbeing than mothers who were not in a relationship (OR 5.61, $p<0.001$ ). Finally, when controlling for the mothers' perceptions of the fairness of the financial arrangement with the father of their child, the results showed that mothers who were having a fair financial arrangement with their expartner had higher odds of reporting high levels of economic well-being than mothers who were having an unfair financial arrangement $(O R 2.18, p<0.001)$. The mothers' ages, their 
Table 1 Descriptive sample statistics: percentages or means (standard deviation)

Sole physical custody families
Asymmetric joint physical custody families
Symmetric joint physical custody families

\begin{tabular}{|c|c|c|c|}
\hline \multicolumn{4}{|l|}{ Dependent variable } \\
\hline \multicolumn{4}{|l|}{ Mother's economic well-being } \\
\hline Very bad to partly bad & 36.4 & 20.5 & 22.9 \\
\hline Good & 49.1 & 52.7 & 53.5 \\
\hline Very good & 14.5 & 26.8 & 23.6 \\
\hline \multicolumn{4}{|l|}{ Independent variable } \\
\hline Physical custody arrangement & 63.0 & 21.6 & 15.4 \\
\hline \multicolumn{4}{|l|}{ Covariates } \\
\hline Mother's age (20-58 years) & $36.8(0.3)$ & $36.9(0.4)$ & $36.7(0.5)$ \\
\hline \multicolumn{4}{|l|}{ Mother's educational level } \\
\hline Low educational level & 17.8 & 12.7 & 7.0 \\
\hline Medium educational level & 44.2 & 46.8 & 36.9 \\
\hline High educational level & 38.0 & 40.5 & 56.1 \\
\hline \multicolumn{4}{|l|}{ Mother's weekly working hours } \\
\hline $0 \mathrm{~h}$ & 11.9 & 5.1 & 7.0 \\
\hline $1-19 \mathrm{~h}$ & 8.9 & 20.1 & 7.0 \\
\hline $20-36 \mathrm{~h}$ & 51.0 & 48.9 & 38.2 \\
\hline More than $36 \mathrm{~h}$ & 28.2 & 25.9 & 47.8 \\
\hline \multicolumn{4}{|l|}{ Mother's monthly personal net income } \\
\hline Less than 1500 euros & 40.9 & 38.9 & 28.6 \\
\hline 1500 euros to less than 2000 euros & 32.4 & 38.7 & 24.4 \\
\hline 2000 euros to less than 3000 euros & 22.7 & 16.5 & 40.4 \\
\hline 3000 euros or more & 4.0 & 5.9 & 6.6 \\
\hline \multicolumn{4}{|l|}{ Mother's number of children } \\
\hline 1 child & 55.1 & 59.5 & 63.1 \\
\hline 2 children & 35.4 & 32.7 & 31.8 \\
\hline More than 2 children & 9.5 & 7.8 & 5.1 \\
\hline Age of the mother's youngest child ( $0-14$ years) & $6.6(0.1)$ & $7.1(0.2)$ & $7.7(0.3)$ \\
\hline \multicolumn{4}{|l|}{ Mother's partnership status } \\
\hline No partner & 50.1 & 48.7 & 47.8 \\
\hline Partner & 49.9 & 51.3 & 52.2 \\
\hline $\begin{array}{l}\text { Time since the separation from the child's father } \\
(0-15 \text { years })\end{array}$ & $4.2(0.1)$ & $3.5(0.2)$ & $3.6(0.2)$ \\
\hline \multicolumn{4}{|l|}{ Fairness of financial arrangement } \\
\hline Unfair & 48.9 & 23.0 & 36.1 \\
\hline Fair & 51.1 & 77.0 & 63.9 \\
\hline $\mathrm{n}$ & 641 & 220 & 157 \\
\hline
\end{tabular}

Family Models in Germany (FAMOD)

educational levels, the age of their youngest child, and the time since the separation were not significantly related to their economic well-being.

\section{Discussion and Concluding Remarks}

\section{Discussion}

Separation or divorce can have detrimental effects on mothers' economic well-being. In addition to the gender-specific 
Table 2 Ordered logistic regression models: the relationship between physical custody arrangements and mothers' economic well-being in post-separation families (odds ratios)

\begin{tabular}{|c|c|c|}
\hline & Model 1 & Model 2 \\
\hline \multicolumn{3}{|l|}{ Physical custody arrangement } \\
\hline Sole physical custody & Ref. & Ref. \\
\hline Asymmetric joint physical custody & $\begin{array}{l}2.20 * * * \\
(0.33)\end{array}$ & $\begin{array}{l}1.78 * * * \\
(0.29)\end{array}$ \\
\hline Symmetric joint physical custody & $\begin{array}{l}1.87 * * * \\
(0.32)\end{array}$ & $\begin{array}{l}1.24 \\
(0.23)\end{array}$ \\
\hline Mother's age & & $\begin{array}{l}1.00 \\
(0.01)\end{array}$ \\
\hline \multicolumn{3}{|l|}{ Mother's educational level } \\
\hline Low educational level & & Ref. \\
\hline Medium educational level & & $\begin{array}{l}0.93 \\
(0.18)\end{array}$ \\
\hline High educational level & & $\begin{array}{l}1.36 \\
(0.28)\end{array}$ \\
\hline \multicolumn{3}{|l|}{ Mother's weekly working hours } \\
\hline $0 \mathrm{~h}$ & & $\begin{array}{l}0.21 * * * \\
(0.06)\end{array}$ \\
\hline $1-19 \mathrm{~h}$ & & $\begin{array}{l}0.93 \\
(0.23)\end{array}$ \\
\hline $20-36 \mathrm{~h}$ & & $\begin{array}{l}0.54 * * * \\
(0.09)\end{array}$ \\
\hline More than $36 \mathrm{~h}$ & & Ref. \\
\hline \multicolumn{3}{|l|}{ Mother's monthly personal net income } \\
\hline Less than 1500 euros & & Ref. \\
\hline 1500 euros to less than 2000 euros & & $\begin{array}{l}1.25 \\
(0.21)\end{array}$ \\
\hline 2000 euros to less than 3000 euros & & $\begin{array}{l}1.98^{* *} \\
(0.40)\end{array}$ \\
\hline 3000 euros or more & & $\begin{array}{l}2.92 * * \\
(0.98)\end{array}$ \\
\hline \multicolumn{3}{|l|}{ Mother's number of children } \\
\hline 1 child & & Ref. \\
\hline 2 children & & $\begin{array}{l}1.00 \\
(0.15)\end{array}$ \\
\hline More than 2 children & & $\begin{array}{l}0.52^{*} \\
(0.14)\end{array}$ \\
\hline Age of the mother's youngest child & & $\begin{array}{l}1.00 \\
(0.03)\end{array}$ \\
\hline \multicolumn{3}{|l|}{ Mother's partnership status } \\
\hline No partner & & Ref. \\
\hline Partner & & $\begin{array}{l}5.61 * * * \\
(0.85)\end{array}$ \\
\hline Time since the separation from the child's father & & $\begin{array}{l}0.96 \\
(0.03)\end{array}$ \\
\hline \multicolumn{3}{|l|}{ Fairness of the financial arrangement } \\
\hline Unfair & & Ref. \\
\hline Fair & & $\begin{array}{l}2.18^{* * *} \\
(0.31)\end{array}$ \\
\hline Pseudo $\mathrm{R}^{2}$ & 0.02 & 0.15 \\
\hline $\mathrm{n}$ & 1018 & 1018 \\
\hline
\end{tabular}

Note. Family Models in Germany (FAMOD); standard errors in parentheses

$* * * \mathrm{p}<0.001, * * \mathrm{p}<0.01, * \mathrm{p}<0.05$ division of labor before separation and the associated negative implications for women's labor market participation, research has shown that mothers' post-separation living arrangements - and, in particular, the physical custody arrangement that the post-separation family practices-are central causes of the observed decline in mothers' economic well-being after separation. Due to the increasing spread of joint physical custody that most Western societies have experienced in recent years, this new post-separation arrangement has come to the attention of scholars; even though the potential implications that practicing joint physical custody may have for the economic well-being of mothers have been largely neglected by previous research. Thus, based on data from the Family Models in Germany (FAMOD) survey, this study investigated differences in the economic well-being of 1018 residential mothers who practiced either sole physical custody, asymmetric joint physical custody, or symmetric joint physical custody.

The results of the estimated ordered logistic regression models showed that mothers with asymmetric and symmetric joint physical custody were more likely to report higher levels of economic well-being than mothers with sole physical custody. When controlling for the mothers' socio-demographic characteristics, the time since their separation from the father of their child, and their perceptions of the fairness of the financial arrangement concerning their child, the differences between mothers with sole physical custody and symmetric joint physical custody disappeared. This finding is in line with the theoretical considerations discussed in this study, which assert that the economic advantages of mothers with joint physical custody can be explained by factors that include the mothers' weekly working hours, their income, their current partnership, and the financial arrangement with their ex-partner. However, the results also showed that the relationship between asymmetric joint physical custody and mothers' economic well-being remained significant, which indicates that there were other factors that accounted for the mothers' positive assessments of their economic situations that were not considered in the theoretical part or in the statistical analysis of this study.

In light of these findings, it should be noted that this study cannot comment on whether practicing joint physical custody has a positive impact on mothers' economic situations, or whether the positive relationship between joint physical custody and mothers' economic well-being can be ascribed to selection processes among post-separation families. From a theoretical point of view, the potential relevance of positive selection into joint physical custody families on the part of the parents cannot be ruled out, especially as the prevalence of joint physical custody is still comparatively low in Germany [with approximately $5 \%$ of all German post-separation families practicing this type of care arrangement after family dissolution (Walper et al., 2020)]. This suggests that 
selection processes may play at least some role in explaining the distribution of care arrangements among post-separation families. It also appears plausible to assume that mothers with a strong attachment to the labor market prior to separation profit the most from the economic advantages associated with living in a joint physical custody family, as their better starting position allows them to take full advantage of the positive features of practicing joint physical custody. While this consideration appears to contradict the findings of an earlier study by Bonnet et al. (2018), in which the authors showed that practicing joint physical custody was particularly beneficial to mothers who were far removed from the labor market, one needs to keep in mind that the societal context and the prevalence of joint physical custody in a given country may influence the relationship between mothers' pre-separation attachment to paid employment, the physical custody type they practice, and their post-separation labor market participation.

\section{Limitations}

The present study has several strengths, including its use of information from a residential calendar, which made it possible to distinguish clearly not only between sole and joint physical custody arrangements, but also between asymmetric and symmetric joint physical custody arrangements, and to include comparatively high numbers of families who were practicing the two types of joint physical custody, which distinguishes this analysis from other empirical studies on the topic of joint physical custody. Nevertheless, this study also has some limitations. The most important limitation is that the FAMOD survey was designed as a convenience sample, which means that the respondents were not sampled using a random sampling strategy. This approach was necessary given the low prevalence of joint physical custody in Germany. However, as was mentioned above, Steinbach et al. (2020) were able to demonstrate that the anchor respondents in the FAMOD study were quite similar to the respondents in other surveys that are representative of the German population of parents in terms of several socio-demographic characteristics (e.g., health and age), which gives the findings of this study some validity. Another limitation is that this study was not able to separate the effect of the mothers' personal income (e.g., in the form of the mothers' wages) from the effect of the mothers' potential child support payments on their economic well-being, as the FAMOD study did not differentiate between the two types of income. In addition, due to the low numbers of non-residential mothers and residential fathers in the FAMOD sample, this study concentrated on the well-being of residential mothers in sole and joint physical custody families. This may seem reasonable given that previous research has suggested that after family dissolution, mothers and their residential children suffer more economically than fathers. Nevertheless, it is of critical importance to also consider fathers' economic wellbeing, as a father may also experience economic hardship and a decline in his living standards in the aftermath of a separation, due to, for example, the obligation to pay child support and the need to find a new dwelling (Assave et al., 2007). Practicing joint physical custody may even add to the negative effects of family dissolution on fathers' economic well-being by requiring a non-residential father to maintain a home that is big enough to accommodate his children for substantial amounts of time. Thus, future studies on joint physical custody should investigate what effects this new physical custody arrangement has on the post-separation economic situations of both mothers and fathers.

\section{Conclusions and Implications}

Taken together, the findings of this study have some implications for policy makers and legal practitioners. Mothers in both symmetric and asymmetric joint physical custody families were shown to fare better in terms of economic well-being than mothers in sole physical custody families. Thus, the results of the statistical analysis seem to suggest that practicing joint physical custody-and in particular asymmetric joint physical custody-benefits mothers' post-separation economic situation. However, as this study was not able to determine the role that selection processes among parents play for the association between physical custody arrangements and mothers' economic well-being, conclusions with respect to the legal praxis have to be drawn carefully. The results of the ordered logistic regression models have also shown that factors like the mothers' weekly working hours and their personal net income were positively related to their levels of economic well-being. These findings highlight the need for policies aimed at promoting mothers' labor market participation; not only after separation or divorce, but also prior to family dissolution in order to put them in a more advantageous post-separation position. One way in which this may be achieved is by expanding affordable and high-quality public childcare. Moreover, previous research has shown that fathers' pre-separation engagement in childcare is positively related to their post-separation engagement (Haux \& Platt, 2020; Haux et al., 2015; Poortman \& van Gaalen, 2017). Based on the assumption that practicing joint physical custody can enhance mothers' job market opportunities, encouraging fathers to get more strongly involved in childrearing responsibilities before family dissolution may be another way in which policies can increase mothers' post-separation economic well-being. Finally, the results of the statistical analysis give rise to the assumption that professional mediation and counseling 
services may benefit mothers' economic well-being by helping separating parents to find a financial arrangement that is fair to both parents - given that the fairness of the financial arrangement with the father of their child was shown to be an important predictor of mothers' economic well-being after family dissolution.

However, this study has also raised new questions with respect to parents' well-being in joint physical custody arrangements. Most importantly, this study could not fully explain the differences in levels of economic well-being between mothers in asymmetric joint physical custody families and mothers in sole physical custody families that remained even after all covariates were included in the regression models. Therefore, future research should investigate what factors account for the higher levels of economic well-being of mothers with asymmetric joint physical custody-particularly as the theoretical considerations on the topic of joint physical custody seem to suggest that mothers with symmetric joint physical custody should have a greater economic advantage. One explanation for the higher levels of economic well-being in mothers with asymmetric joint physical custody may be related to living expenses in different joint physical custody arrangements. Practicing symmetric joint physical custody may be associated with higher costs than practicing asymmetric joint physical custody. In a symmetric joint physical custody arrangement, children divide their time equally between the two parents, which makes it more likely that the parents have to spend more money on, for example, two residences that are big enough to accommodate the children and two sets of clothes and toys for the children. Because children living in asymmetric joint physical custody families spend considerably less time with their non-residential parent (in some cases, not more than $30 \%$ of the time), their living expenses may be lower, which should benefit mothers' economic well-being-not just directly, but also indirectly through, for example, the greater amount of money that fathers are able to spend on their children. Additionally, given that the institutional context of a country shapes the economic consequences of separation by, for example, setting the framework conditions for women's labor market participation and by providing legal regulations regarding women's rights and financial support (Andreß et al., 2006; de Vaus et al., 2015), international studies are needed to test whether the findings of this study on the effects of asymmetric and symmetric joint physical custody can be replicated with data from other countries; and thus to shed light on the question of whether these findings are unique for the German context, or whether they apply to other countries as well.

Author Contributions Not applicable.
Funding Open Access funding enabled and organized by Projekt DEAL. This work was supported by the German Research Foundation under Project Number 394377103.

Data Availability The data that support the findings of this study are openly available at GESIS Data Archive (https://search.gesis.org/resea rch_data/ZA6849, https://doi.org/10.4232/1.13571).

Code Availability Not applicable.

\section{Declarations}

Conflict of interest No potential conflict of interest was reported by the author.

Ethical Approval The study was not presented to a research ethics committee, because an approval was not requested by the German Research Foundation (DFG) due to the de-identified and public nature of the data.

Consent to Participate Informed consent was obtained from all individual participants included in the study.

Consent for Publication Not applicable.

Open Access This article is licensed under a Creative Commons Attribution 4.0 International License, which permits use, sharing, adaptation, distribution and reproduction in any medium or format, as long as you give appropriate credit to the original author(s) and the source, provide a link to the Creative Commons licence, and indicate if changes were made. The images or other third party material in this article are included in the article's Creative Commons licence, unless indicated otherwise in a credit line to the material. If material is not included in the article's Creative Commons licence and your intended use is not permitted by statutory regulation or exceeds the permitted use, you will need to obtain permission directly from the copyright holder. To view a copy of this licence, visit http://creativecommons.org/licenses/by/4.0/.

\section{References}

Amato, P. R., Meyers, C. E., \& Emery, R. E. (2009). Changes in nonresident father-child contact from 1976 to 2002. Family Relations, 58(1), 41-53. https://doi.org/10.1111/j.1741-3729.2008.00533.x

Andreß, H.-J., Borgloh, B., Bröckel, M., Giesselmann, M., \& Hummelsheim, D. (2006). The economic consequences of partnership dissolution-A comparative analysis of panel studies from Belgium, Germany, Great Britain, Italy, and Sweden. European Sociological Review, 22(5), 533-560. https://doi.org/10.1093/esr/ jc1012

Assave, A., Betti, G., Mazzuco, S., \& Mencarini, L. (2007). Marital disruption and economic well-being: A comparative analysis. Journal of the Royal Statistical Society: Series A (Statistics in Society), 170(3), 781-799. https://doi.org/10.1111/j.1467-985X. 2007.00483.x

Bakker, W., \& Karsten, L. (2013). Balancing paid work, care and leisure in post-separation households: A comparison of single parents with co-parents. Acta Sociologica, 56(2), 173-187. https:// doi.org/10.1177/0001699312466178

Bakker, W., \& Mulder, C. H. (2013). Characteristics of post-separation families in the Netherlands: Shared residence versus resident mother arrangements. GeoJournal, 78(5), 851-866. https://doi. org/10.1007/s10708-012-9470-x 
Bauserman, R. (2012). A meta-analysis of parental satisfaction, adjustment, and conflict in joint custody and sole custody following divorce. Journal of Divorce \&amp; Remarriage, 53(6), 464-488. https://doi.org/10.1080/10502556.2012.682901

Becker, G. S. (1981). A treatise on the family. Harvard University Press.

Bonnet, C., Garbinti, B., \& Solaz, A. (2018). Does part-time mothering help get a job? The role of shared custody in women's employment. CASEpaper 209. Centre for Analysis of Social Exclusion. https://ideas.repec.org/p/cep/sticas/-209.html

Bröckel, M., \& Andreß, H.-J. (2015). The economic consequences of divorce in Germany: What has changed since the turn of the millennium? Comparative Population Studies, 40(3), 277-312. https://doi.org/10.12765/CPoS-2015-04en

Cancian, M., Meyer, D. R., Brown, P. R., \& Cook, S. T. (2014). Who gets custody now? Dramatic changes in children's living arrangements after divorce. Demography, 51(4), 1381-1396. https://doi. org/10.1007/s13524-014-0307-8

Cashmore, J., Parkinson, P., Weston, R., Patulny, R., Redmond, G., Qu, L., Baxter, J., Rajkovic, M., Sitek, T., \& Katz, I. (2010). Shared care parenting arrangements since the 2006 family law reforms: Report to the Australian government attorney-general's department. Social Policy Research Centre, University of New South Wales. https://www.arts.unsw.edu.au/sites/default/files/docum ents/2_AG_Shared_Care.pdf

Cheadle, J. E., Amato, P. R., \& King, V. (2010). Patterns of nonresident father contact. Demography, 47(1), 205-225. https://doi.org/10. 1353/dem.0.0084

de Graaf, P. M., \& Kalmijn, M. (2003). Alternative routes in the remarriage market: Competing-risk analyses of union formation after divorce. Social Forces, 81(4), 1459-1498. https://doi.org/10.1353/ sof.2003.0052

de Vaus, D., Gray, M., Qu, L., \& Stanton, D. (2015). The economic consequences of divorce in six OECD countries. https://onlinelibr ary.wiley.com/doi/abs/10.1002/ajs4.13

Emery, R. E., Otto, R. K., \& O'Donohue, W. T. (2005). A critical assessment of child custody evaluations: Limited science and a flawed system. Psychological Science in the Public Interest, 6(1), 1-29. https://doi.org/10.1111/j.1529-1006.2005.00020.x

Hancioglu, M., \& Hartmann, B. (2014). What makes single mothers expand or reduce employment? Journal of Family and Economic Issues, 35(1), 27-39. https://doi.org/10.1007/s10834-013-9355-2

Haux, T., \& Platt, L. (2020). Fathers' involvement with their children before and after separation. European Journal of Population. https://doi.org/10.1007/s10680-020-09563-z

Haux, T., Platt, L., \& Rosenberg, R. (2015). Parenting and post-separation contact: What are the links? CASE Papers/189, Centre for Analysis of Social Exclusion, LSE.

Hofferth, S. L., Forry, N. D., \& Peters, H. E. (2010). Child support, father-child contact, and preteens' involvement with nonresidential fathers: Racial/ethnic differences. Journal of Family and Economic Issues, 31(1), 14-32. https://doi.org/10.1007/ s10834-009-9172-9

Ivanova, K., Kalmijn, M., \& Uunk, W. (2013). The effect of children on men's and women's chances of re-partnering in a European context. European Journal of Population, 29(4), 417-444. https:// doi.org/10.1007/s10680-013-9294-5

Jansen, M., Mortelmans, D., \& Snoeckx, L. (2009). Repartnering and (re)employment: Strategies to cope with the economic consequences of partnership dissolution. Journal of Marriage and Family, 71(5), 1271-1293. https://doi.org/10.1111/j.1741-3737. 2009.00668.x

Juby, H., Le Bourdais, C., \& Marcil-Gratton, N. (2005). Sharing roles, sharing custody? Couples' characteristics and children's living arrangements at separation. Journal of Marriage and
Family, 67(1), 157-172. https://doi.org/10.1111/j.0022-2445. 2005.00012.x

Kantar Public. (2020). FAMOD-Familienmodelle in Deutschland. Methodenbericht. GESIS Datenarchiv, Köln. ZA6849 Datenfile Version 1.0.0. https://doi.org/10.4232/1.13571

Kessler, D. (2018). The consequences of divorce for mothers and fathers: Unequal but converging? Lives Working Paper 2018/71. https://doi.org/10.12682/lives.2296-1658.2018.71

Kitterød, R. H., \& Lyngstad, J. (2012). Untraditional caring arrangements among parents living apart: The case of Norway. Demographic Research, 27, 121-152. https://doi.org/10.4054/DemRes. 2012.27.5

Köppen, K., Kreyenfeld, M., \& Trappe, H. (2020). Gender differences in parental well-being after separation: Does shared parenting matter? In M. Kreyenfeld \& H. Trappe (Eds.), Parental life courses after separation and divorce in Europe (pp. 235-264). Springer.

Leopold, T. (2018). Gender differences in the consequences of divorce: A study of multiple outcomes. Demography, 55(3), 769-797. https://doi.org/10.1007/s13524-018-0667-6

Meyer, D. R., Cancian, M., \& Cook, S. T. (2017). The growth in shared custody in the United States: Patterns and implications. Family Court Review, 55(4), 500-512. https://doi.org/10.1111/fcre.12300

Mortelmans, D. (2020). Economic consequences of divorce: A review. In M. Kreyenfeld \& H. Trappe (Eds.), Parental life courses after separation and divorce in Europe (pp. 23-41). Springer.

Needles Fletcher, C., \& Lorenz, F. O. (1985). Structural influences on the relationship between objective and subjective indicators of economic well-being. Social Indicators Research, 16(3), 333-345. https://doi.org/10.1007/BF00415130

Osborne, C., Berger, L. M., \& Magnuson, K. (2012). Family structure transitions and changes in maternal resources and wellbeing. Demography, 49(1), 23-47. https://doi.org/10.1007/ s13524-011-0080-x

Poortman, A.-R. (2000). Sex differences in the economic consequences of separation. A panel study of the Netherlands. European Sociological Review, 16(4), 367-383. https://doi.org/10.1093/esr/16.4. 367

Poortman, A.-R., \& van Gaalen, R. (2017). Shared residence after separation: A review and new findings from the Netherlands. Family Court Review, 55(4), 531-544. https://doi.org/10.1111/fcre.12302

Radenacker, A. (2020). Changes in mothers' earnings around the time of divorce. In M. Kreyenfeld \& H. Trappe (Eds.), Parental life courses after separation and divorce in Europe (pp. 65-81). Springer.

Raley, R. K., \& Sweeney, M. M. (2020). Divorce, repartnering, and stepfamilies: A decade in review. Journal of Marriage and Family, 82(1), 81-99. https://doi.org/10.1111/jomf.12651

Schneider, S. (2021). Bedingungen für die kindeswohldienliche Praktizierung des Wechselmodells. Wolfgang Metzner Verlag.

Schnor, C., Pasteels, I., \& van Bavel, J. (2017). Sole physical custody and mother's repartnering after divorce. Journal of Marriage and Family, 79(3), 879-890. https://doi.org/10.1111/jomf.12389

Sodermans, A. K., Botterman, S., Havermans, N., \& Matthijs, K. (2015). Involved fathers, liberated mothers? Joint physical custody and the subjective well-being of divorced parents. Social Indicators Research, 122(1), 257-277. https://doi.org/10.1007/ s11205-014-0676-9

Sodermans, A. K., Vanassche, S., Matthijs, K., \& Swicegood, G. (2014). Measuring postdivorce living arrangements: Theoretical and empirical validation of the residential calendar. Journal of Family Issues, 35(1), 125-145. https://doi.org/10.1177/01925 13 X12464947

Spruijt, E., \& Duindam, V. (2009). Joint physical custody in the Netherlands and the well-being of children. Journal of Divorce \& amp; 
Remarriage, 51(1), 65-82. https://doi.org/10.1080/1050255090 3423362

Steinbach, A. (2019). Children's and parents' well-being in joint physical custody: A literature review. Family Process, 58(2), 353-369. https://doi.org/10.1111/famp.12372

Steinbach, A., \& Augustijn, L. (2021). Post-separation parenting time schedules in joint physical custody arrangements. Journal of Marriage and Family, 83(2), 595-607. https://doi.org/10.1111/jomf. 12746

Steinbach, A., Brocker, S. A., \& Augustijn, L. (2020). The survey on "Family Models in Germany" (FAMOD). A description of the data. Duisburger Beiträge zur soziologischen Forschung 2020-01. https://doi.org/10.6104/DBsF-2020-01

Struffolino, E., \& Mortelmans, D. (2018). Lone mothers in Belgium: Labor force attachment and risk factors. In L. Bernardi \& D. Mortelmans (Eds.), Lone parenthood in the life course (pp. 257282). Springer.

Turunen, J. (2017). Shared physical custody and children's experience of stress. Journal of Divorce \&amp; Remarriage, 58(5), 371-392. https://doi.org/10.1080/10502556.2017.1325648

Vanassche, S., Sodermans, A. K., Declerck, C., \& Matthijs, K. (2017). Alternating residence for children after parental separation:
Recent findings from Belgium. Family Court Review, 55(4), 545-555. https://doi.org/10.1111/fcre.12303

Walper, S., Amberg, S., \& Langmeyer, A. N. (2020). Familien mit getrennten Eltern. In J. Ecarius, \& A. Schierbaum (Eds.), Handbuch Familie. Gesellschaft, Familienbeziehungen und differentielle Felder (pp. 1-19). Springer VS. https://doi.org/10.1007/ 978-3-658-19416-1_28-1

Publisher's Note Springer Nature remains neutral with regard to jurisdictional claims in published maps and institutional affiliations.

Lara Augustijn holds a PhD in sociology. She works as research associate at the Department of Sociology of the University of DuisburgEssen. Her focus is on family and health studies, with a particular interest in post-separation families, parents' and children's health and well-being, and intergenerational transmission. 